\title{
Primary HIV infection: the French experience
}

\author{
Cécile Goujard \\ From 17th International Symposium on HIV and Emerging Infectious Diseases (ISHEID) \\ Marseille, France. 23-25 May 2012
}

The ANRS PRIMO is a prospective multicenter French Cohort which had enrolled 1433 patients during primaryHIV-1 infection (PHI) since 1996, with the objectives to improve pathophysiological knowledge on PHI, to assess the impact of an early antiretroviral treatment and to contribute to document the epidemiology of new infections in France. Clinical and laboratory data are collected at inclusion, month (M)1, M3, M6, and then every 6 months. All patients are antiretroviral-naïve at inclusion.

Patients were included early after infection (median time, 31 days; $26 \%$ acute infection); $84 \%$ were men. The $\%$ of patients infected with non-B subtypes increased in the last decade, while the frequency of resistant viral strains remained stable. At inclusion, median CD4 cell counts and viral HIV load were $518 / \mathrm{mm}^{3}$ and $5.1 \log _{10}$ copies $/ \mathrm{mL}$ at PHI, with a wide range of values in the whole population (IQR, 372-678/ $\mathrm{mm}^{3}$ and 4.5-5.7 log respectively), depending only partially to the time from infection. Median cellular DNA at inclusion was $3.4 \log \mathrm{cp} / 10^{6} \mathrm{PBMCs}$ (IQR, 2.9-3.7). Early immunological (CD4 counts) and virological parameters (HIV RNA and DNA) could predict the risk of progression to a CD4 count $<350$ cells $/ \mathrm{mm}^{3}$ in untreated patients and the chance of spontaneous persistent control of viral replication after infection. $52 \%$ of patients initiated an antiretroviral treatment at inclusion. Although a transient treatment during PHI did not translate into a benefit in terms of viral set-point compared to untreated patients, it could lead to long term preservation of CD4 cell counts. Furthermore, we showed that rare treated patients were capable of controlling viral replication after treatment interruption, those patients had lower viral reservoir at inclusion before treatment and at treatment interruption compared to non controllers. Cellular activation was high during PHI and declined substantially thereafter, with lower levels in patients treated early after infection compared to patients treated during the chronic phase.

General Hospital of Bicêtre, Kremlin-Bicêtre, France
Antiretroviral treatment is now given in less advanced infection and even discussed as a universal approach to prevent HIV transmission. The question of treatment initiation in all patients diagnosed during PHI is relevant.

Published: 25 May 2012

doi:10.1186/1742-4690-9-S1-I14

Cite this article as: Goujard: Primary HIV infection: the French

experience. Retrovirology 2012 9(Suppl 1):114.
Submit your next manuscript to BioMed Central and take full advantage of:

- Convenient online submission

- Thorough peer review

- No space constraints or color figure charges

- Immediate publication on acceptance

- Inclusion in PubMed, CAS, Scopus and Google Scholar

- Research which is freely available for redistribution

Submit your manuscript at www.biomedcentral.com/submit
() Bïomed Central
( 2012 Goujard; licensee BioMed Central Ltd. This is an Open Access article distributed under the terms of the Creative Commons Attribution License (http://creativecommons.org/licenses/by/2.0), which permits unrestricted use, distribution, and reproduction in any medium, provided the original work is properly cited. 